\title{
»In Christ« in Paul
}

\section{Explorations in Paul's Theology of Union and Participation Ed. by Michael J. Thate, Kevin J. Vanhoozer and Constantine R. Campbell}

[»In Christus sein« bei Paulus. Untersuchungen von Paulus' Theologie der Einheit und Partizipation.]

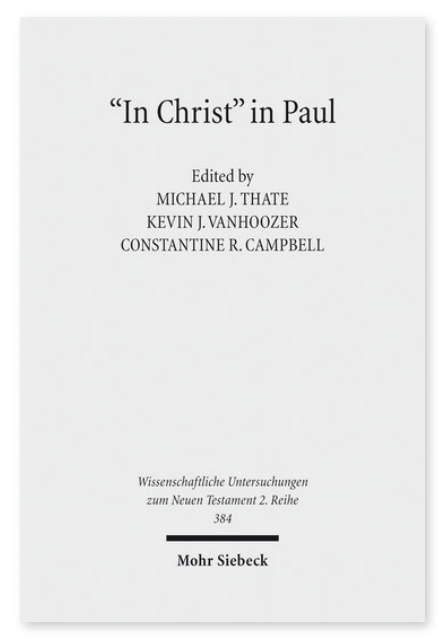

2014. IX, 577 Seiten. WUNT II 384

ISBN 978-3-16-153552-9

DOI 10.1628/978-3-16-153552-9

eBook PDF 129,00€

ISBN 978-3-16-152387-8

fadengeheftete Broschur 129,00€
Veröffentlicht auf Englisch.

Vor beinahe 35 Jahren machte E.P. Sanders die berühmte Aussage, dass der zentrale Gedanke in der Theologie des Paulus in der Teilhabe läge - was natürlich eine große Debatte innerhalb der paulinischen Forschung auslöste. Sanders meinte auch, dass wir keine moderne Vorstellung davon haben, was dieser Gedanke heutzutage für uns bedeutet. Diese beiden Axiome bilden das grobe Gerüst für die Beiträge dieses Bandes, die die komplexen Gedankengänge von Einheit und Partizipation innerhalb der paulinischen Theologie durch Exegese, Höhepunkte in der Rezeptionsgeschichte und theologische Reflektion untersuchen.

\section{Inhaltsübersicht}

Kevin J. Vanhoozer: From »Blessed in Christ (Eph 1:3) to »Being in Christ«: The State of the Union and the Place of Participation in Paul's Discourse, New Testament Exegesis, and Systematic Theology Today Part One: Pauline Theology and Exegesis Douglas A. Campbell: Participation and Faith in Paul - Constantine R. Campbell: Metaphor, Reality, and Union with Christ - Grant Macaskill: Incarnational Ontology and the Theology of Participation in Paul - Susan Eastman: Oneself in Another: Participation and the Spirit in Romans 8 - Matthew Croasmun: »Real Participation«: The Body of Christ \& the Body of Sin in Evolutionary Perspective - Isaac Augustine Morales, O.P.: Baptism and Union with Christ - MichaelJ. Gorman: Paul's Corporate, Cruciform, Missional Theosis in 2 Corinthians - MichaelJ. Thate: Paul and the Anxieties of (Imperial?) Succession: Galatians and the Politics of Neglect - Joshua W. Jipp: Sharing the Heavenly Rule of Christ the King: Paul's Royal Participatory Language in Ephesians - MichaelJ. Thate: Paul, Фpóvnoıs, and Participation: The Shape of Space and the Reconfiguration of Place in Paul's Letter to the Philippians Part Two: Some Highlights from Reception History Ben C. Blackwell: Two Early Perspectives on Participation in Paul: Irenaeus and Clement of Alexandria - Darren Sarisky: Augustine and Participation: Some Reflections on His Exegesis of Romans - Stephen Chester: Union with Christ: Martin Luther - Julie Canlis: The Fatherhood of God \& Union with Christ in Calvin - T. Robert Baylor: „One with Him in Spirit«: Mystical Union and the Humanity of Christ in the Theology of John Owen - Keith L. Johnson: Karl Barth's Reading of Paul's Union with Christ Part Three: Theological Reflection Ashish Varma: Fitting Participation: From the Holy Trinity to Christian Virtue - Mary Patton Baker: Participating in the Body and Blood of Christ: Christian Kolvwví $\alpha$ and the Lord's Supper - Devin P. Singh: Until We Are One? Biopolitics and the United Body

Constantine R. Campbell Born 1975; 2007 PhD; currently Associate Professor of New Testament at Trinity Evangelical Divinity School, Deerfield, IL, USA.

Michael J. Thate Born 1978; 2012 PhD; currently a Post-Doctoral Research Associate at Princeton University.

Kevin J. Vanhoozer Born 1957; 1985 PhD; currently Research Professor of Systematic Theology at Trinity Evangelical Divinity School, Deerfield, IL, USA.

Jetzt bestellen:

https://mohrsiebeck.com/buch/in-christ-in-paul-9783161535529?no_cache=1

order@mohrsiebeck.com

Telefon: $+49(0) 7071-923-17$

Telefax: $+49(0) 7071-51104$ 